\title{
PELUANG TENAGA KERJA INDONESIA DALAM MENGHADAPI MEA
}

\author{
Onsardi \\ Dosen Universitas Muhammadiyah Bengkulu \\ onsardi@umb.ac.id
}

\begin{abstract}
Abstrak
Era MEA sudah dimulai, maka akan menyebabkan aliran tenaga kerja antar negara Asean termasuk Indonesia. Kemungkinan Indonesia akan menjadi tempat untuk migrasi tenaga kerja terdidik. Apakah kita siap menerima aliran tenaga kerja asing? Selama ini tenaga kerja kita lebih mengutamakan gaji yang tinggi untuk memenuhi kebutuhannya dan bukan prestasi kerja yang diutamakan. Hal ini merupakan tantangan pertama dari MEA, yaitu negara-negara di kawasan Asia Tenggara ini akan dijadikan sebuah wilayah kesatuan pasar dan basis produksi, sehingga arus barang, jasa, investasi, modal dalam jumlah yang besar, dan tenaga kerja terlatih menjadi tidak ada hambatan dari satu negara ke negara lainnya di kawasan Asia Tenggara. Dengan hadirnya MEA diharapkan akan memperkuat daya saing dalam bidang ketenagakerjaan. Umumnya tenaga kerja di Indonesia tidak terdidik yang mencapai lebih dari $60 \%$ dari jumlah penduduk. Penting juga diperhatikan adalah kemudahan untuk memperoleh pekerjaan mulai dari permodalan, keahlian, hingga regulasi yang mendukung. Dengan tujuan akhir bahwa sudah saatnya masyarakat Indonesia menjadi mandiri dan sejahtera dengan memaksimalkan semua potensi yang ada.
\end{abstract}

Kata Kunci: MEA, tenaga kerja,

\section{A. PENDAHULUAN}

Pertemuan Menteri Ekonomi ASEAN yang dilaksanakan pada bulan Agustus 2006 di Kuala Lumpur, Malaysia, sepakat untuk mengembangkan AEC Blueprint yang merupakan pedoman bagi negara-negara anggota ASEAN untuk mencapai AEC 2015. AEC Blueprint memuat 4 (empat) kerangka utama/ pilar, yaitu :

1. ASEAN sebagai pasar tunggal dan basis produksi internasional dengan elemen aliran bebas barang, jasa, investasi, tenaga kerja terdidik dan aliran modal yang lebih bebas;

2. ASEAN sebagai kawasan dengan daya saing ekonomi yang tinggi, dengan elemen peraturan kompetisi, perlindungan konsumen, hak atas kekayaan intelektual, pengembangan infrastruktur, perpajakan dan e-commerce;

3. ASEAN sebagai kawasan dengan pengembangan ekonomi yang merata dengan elemen pengembangan usaha kecil dan menengah, dan prakarsa integrasi ASEAN untuk negara-negara CMLV (Cambodia, Myanmar, Laos, dan Vietnam); 
4. ASEAN sebagai kawasan yang terintegrasi secara penuh dengan perekonomian global dengan elemen pendekatan yang koheren dalam hubungan ekonomi di luar kawasan, dan meningkatkan peran serta dalam jejaring produksi global. Dalam penerapannya pada tahun 2015, MEA akan menerapkan 12 sektor prioritas yang dibagi dalam dua bagian yaitu tujuh sektor barang industri dan lima sektor jasa. Ketujuh sektor barang industri terdiri atas produk berbasis pertanian, elektronik, perikanan, produk berbasis karet, tekstil, otomotif, dan produk berbasis kayu. Sedangkan kelima sektor jasa tersebut adalah transportasi udara, E-Asean, pelayanan kesehatan, turisme dan jasa logistik.

Indonesia memasuki era Masyarakat Ekonomi ASEAN (MEA) yang memungkinkan arus barang, modal dan jasa antar negara ASEAN tidak lagi mengalami hambatan. Tujuannya adalah meliberalisasi arus barang, jasa, tenaga kerja, investasi dan modal untuk meningkatkan kemakmuran dan daya saing kawasan. Untuk arus barang dilakukan dengan pengurangan dan penghilangan hambatan tarif atau bea masuk. Sedang untuk arus modal dilakukan dengan deregulasi persetujuan penanaman modal. Untuk liberalisasi arus tenaga kerja, secara spesifik akan ada perjanjian arus bebas tenaga kerja terampil seperti perawat, akuntan, jasa arsitek, dan praktisi kedokteran.

Konsep perdagangan bebas pertama kali diusung oleh World Trade Organization (WTO). Sehingga suatu negara yang menjadi anggota WTO secara otomatis harus bersedia membuka pasar bagi negara lain dan menerima segala konsekuensi perdagangan bebas tersebut. Namun demikian sampai sejauh ini, tidak ada satu negara pun, khususnya negara maju seperti Uni Eropa dan Amerika Serikat yang sepenuh hati mau membuka kran bagi kebebasan impor. Walaupun mayoritas dari mereka berpandangan bahwa liberalisme akan mendatangkan keuntungan bagi semua pihak, di mana perdagangan bebas akan mendorong tumbuhnya konsumsi dan keuntungan bagi semua pihak dikarenakan adanya perbedaan keunggulan komparatif relatif antarnegara dalam menghasilkan komoditas.

Sektor jasa adalah salah satu sektor yang belakangan ini mendapatkan perhatian khusus dari berbagai pihak di Indonesia. menyampaikan bahwa peran sektor jasa dalam perdagangan internasional sangat penting dan oleh karena itu sangat penting bagi Indonesia untuk terus mendukung sektor tersebut. Semakin maju perekonomian suatu negara, sektor jasa menjadi semakin penting dan 
melampaui pentingnya sektor agrikultur dan industri. Pandangan senada juga disampaikan oleh Menteri Perindustrian, M.S. Hidayat, yang menyampaikan bahwa sektor jasa adalah sektor yang penting dalam perekonomian Indonesia dan menyumbang sekitar $60-80 \%$ dalam penurunan kemiskinan di Indonesia. Sebagaimana dicatat oleh Chris Manning dan Haryo Aswicahyono (2012), Indonesia mengalami fenomena yang berbeda dengan negara-negara lain di Asia Tenggara dalam hal perbandingan antara pertumbuhan sektor jasa dan sektor manufaktur. Setelah krisis ekonomi pada tahun 1997/1998, jasa tercatat tumbuh jauh lebih cepat dibandingkan manufaktur yang tumbuh dengan sangat lambat. Kondisi ini berbeda jika dibandingkan dengan Thailand dan

Malaysia di mana sektor manufaktur berkembang sama cepatnya dengan sektor jasa di kedua negara tetangga tersebut (meskipun tetap lebih lambat dibandingkan dengan pertumbuhan di masa sebelum krisis Asia 1997/1998).2Walaupun terdapat berbagai pihak seperti misalnya Asosiasi Pengusaha Indonesia (Apindo) DKI yang mengakui bahwa tenaga kerja lokal memiliki softskill yang lebih baik dibandingkan dengan tenaga kerja asing.

\section{B. PERMASALAHAN}

Apakah tenaga kerja Indonesia mampu bersaing dengan tenaga kerja asing dalam menghadapi Masyarakat Ekonomi Asean (MEA)?

\section{KAJIAN PUSTAKA}

Dalam upaya meningkatkan liberalisasi perdagangan jasa, WTO kemudian membentuk GATS (General Agreements on Trade in Services) mengatur liberalisasi perdagangan sektor jasa. GATS menganut beberapa prinsip utama yaitu: yaitu prinsip non-diskriminasi yang terdiri dari most favoured nation principle (MFN Principle) dan national treatment, prinsip liberalisasi akses pasar, serta prinsip transparansi. Bila Asean Economic Community atau kemudian dikenal dengan Masyarakat Ekonomi Asean (MEA) akan terwujud, maka akan menyebabkan arus tenaga kerja asing dari satu negara ke negara lain seperti Indonesia tanpa hambatan. Perdagangan jasa di mana tenaga kerja dibedakan menjadi dua yaitu tenaga kerja trampil (skilled labor) dan tenaga kerja tidak terampil (unskilled labor). Pengertian dari skilled labor adalah tenaga kerja yang mempunyai keterampilan,, keahlian khusus, pengetahuan,atau kemampuan di bidangnya, yang bisa berasal dari lulusan perguruan tinggi , akademisi atau 
sekolah teknik atau dari pengalaman kerja. Blueprint ini tidak mengatur atau menyebut mengenai tenaga kerja yang tidak terampil (unskilled labor). Hal ini tercermin dengan prinsip yang terdapat dalam GATS yang secara rinci mengatur ruang lingkup perdagangan jasa seperti yang tercantum Pasal 1 dan 2 yang meliputi empat mode pasokan (modes of supply) yaitu:

1. Mode 1 adalah pasokan lintas batas (cross border supply) yaitu penyediaan jasa di dalam suatu wilayah negara anggota untuk melayani pemakai jasa dari negara anggota lainnya.

2. Mode 2 adalah konsumsi luar negeri (consumption abroad) yaitu penyediaan jasa dari dalam wilayah suatu negara anggota ke dalam wilayah negara anggota lainnya.

3. Mode 3 adalah kehadiran komersial (commercial presence) yaitu penyediaan jasa oleh penyedia jasa dari suatu negara anggota melalui kehadiran perusahaan jasa di dalam wilayah negara anggota lainnya.

4. Mode 4 adalah pergerakan manusia (movement of natural person) yaitu pernyediaan jasa oleh penyedia jasa dari satu negara anggota melalui kehadiran natural person dari suatu negara anggota di dalam wilayah negara anggota.

Dalam AEC atau MEA seluruh negara Asean harus melakukan liberalisasi perdagangan, barang, jasa, investasi, tenaga kerja terampil, secara bebas dan arus modal yang lebih bebas seperi yang digariskan dalam blueprint AEC. Kemungkinan masuknya tenaga kerja asing antar negara dalam rangka kerja sama bila dilihat berdasarkan modes of supply maka yang paling tepat adalah menggunakan mode 4 . Kerja sama dalam mode 4 digunakan untuk memfasilitasi pergerakan tenaga kerja yang didasarkan pada suatu kontrak/perjanjian untuk mendukung kegiatan perdagangan dan investasi si sektor jasa.

\section{PEMBAHASAN}

Indonesia pada tahun 2014 telah mengundangkan UU No. 7 Tahun 2014 sebagai upaya harmonisasi ketentuan di bidang perdagangan dalam kerangka kesatuan ekonomi nasional guna menyikapi perkembangan situasi perdagangan era globalisasi pada masa kini dan masa depan, deikian yang tercantum dalam pertimbangan penerbitan UU No. 7 tahun 2014. UU Perdagangan 2014 juga mengenal perdagangan barang dan perdagangan jasa. Wakil Menteri Perdagangan (Wamendag) Bayu Krishnamurti menjelaskan UU Perdagangan mencakup bukan hanya barang tetapi juga jasa yang bisa diperdagangkan (trade 
on services). Sektor jasa ini sengaja dimasukkan ke dalam UU Perdagangan guna menghadapi Masyarakat Ekonomi ASEAN atau MEA 2015 mendatang. Setidaknya ada tiga pasal yang mengatur tentang bidang jasa dalam UU Perdagangan dan menjadi bagian penting dalam pelaksanaan MEA 2015, yakni pasal 4 ayat (2), pasal 20 dan pasal 21. Lingkup pengaturan bidang jasa, sebagaimana diatur dalam Pasal 2 ayat (2) meliputi 12 sektor yakni, jasa bisnis, jasa distribusi, jasa komunikasi, jasa pendidikan, jasa lingkungan hidup, jasa keuangan, jasa konstruksi dan teknik terkait, jasa kesehatan sosial, jasa rekreasi, kebudayaan dan olahraga, jasa pariwisata, jasa transportasi dan jasa lainnya.

Dalam pasal 20 UU No. 7 tahun 2014 menyebutkan Penyedia Jasa yang bergerak di bidang Perdagangan Jasa wajib didukung tenaga teknis yang kompeten sesuai dengan ketentuan peraturan perundang-undangan. Penyedia Jasa yang tidak memiliki tenaga teknis yang kompeten dikenai sanksi administratif berupa peringatan tertulis, penghentian sementara kegiatan usaha, atau atau Pencabutan izin usaha. Dalam Pasal 21 UU Perdagangan, dijelaskan bahwa pemerintah dapat memberi pengakuan terhadap kompentensi tenaga teknis dari negara lain berdasarkan perjanjian saling pengakuan secara bilateral atau regional. Menurut Wamendag Bayu, pasal ini menjadi strategis bagi Kemendag karena selama ini belum memiliki dasar hukum yang jelas dalam hal melakukan negosiasi dengan negara-negara lain.

Bila dikaitkan dengan permasalahan tenaga kerja di Indonesia telah banyak kajian yang membahasnya, terutama dari ratio antara tenaga kerja dengan jumlah total penduduk Indonesia. Selain itu juga terdapat beberapa hal yang perlu menjadi perhatian atau catatan bagi dunia ketenagakerjaan sebelum saatnya negara kita benar-benar akan memasuki MEA.

1. Dari sisi peraturan perundang-undangan di bidang ketenagakerjaan.

Meskipun sumber hukum ketenagakerjaan di Indonesia terdapat ketentuan hukum yang tersebar di berbagai peraturan perundang-undangan, Undang-Undang Nomor 13 Tahun 2003 Tentang Ketenagakerjaan merupakan peraturan pokok yang berisi pengaturan secara menyeluruh dan komprehensif di bidang ketenagakerjaan. Hal inilah yang menjadi pegangan sebagai aturan main dunia ketenagakerjaan di Indonesia saat memasuki MEA.

2. Dari sisi Sumber Daya Manusia (SDM) pekerja Indonesia. 
Kompetisi SDM antar negara ASEAN merupakan hal yang pasti terjadi saat terbukanya gerbang MEA nanti. Bila pekerja Indonesia tidak siap menghadapi persaingan terbuka ini, MEA akan menjadi momok bagi pekerja Indonesia karena akan kalah bersaing dengan pekerja dari negara ASEAN lainnya. Rendahnya kualitas pendidikan formal tenaga kerja Indonesia ini jelas sangat mengkhawatirkan. Dengan sisa waktu yang sangat sempit ini, Pemerintah perlu mencari terobosan dan cara singkat untuk meningkatkan keterampilan dan kompetensi kerja bagi SDM kita yang sesuai dengan kebutuhan pasar MEA nantinya dan bukan hanya terobosan yang sifatnya normatif melalui Peraturan perundang-undangan. Bila rendahnya kualitas tenaga kerja (unskilled labor) Indonesia akan mendorong arus tenaga kerja antarnegara akan menguasai jagat Indonesia. Daya saing kemampuan tenaga kerja Indonesia harus ditingkatkan baik secara formal maupun informal. Kemampuan harus memenuhi standar minimal yang telah ditetapkan oleh MRA. Sebenarnya penerapan Mode 3 mengenai pendirian perusahaan (commercial presence) dan Mode 4 berupa mobilitas tenaga kerja (Movement of natural persons) intra Asean akan diberlakukan untuk sektor prioritas integrasi. Untuk itu Indonesia harus dapat meningkatkan kualitas tenaga kerjanya sehingga bisa digunakan baik di dalam negeri atau antar Asean. Untuk mencegah banjirnya tenaga terampil dari luar.

3. Pengawas Ketenagakerjaan.

Jumlah pengawas ketenagakerjaan sangat tidak seimbang dengan jumlah perusahaan, sehingga perlu dicari terobosan oleh pemerintah untuk menambah jumlah penegak hukum. Seharusnya pengawasan dilaksanakan sesuai dengan ketentuan dalam Pasal 134 Undang-Undang Nomor 13 Tahun 2003 tentang Ketenagakerjaan yang menyebutkan bahwa "Dalam mewujudkan pelaksanaan hak dan kewajiban pekerja/buruh dan pengusaha, pemerintah wajib melaksanakan pengawasan dan penegakan peraturan perundang-undangan ketenagakerjaan". Dalam menghadapi MEA, posisi pengawas ketenagakerjaan menjadi hal yang sangat penting dalam hubungan industrial agar semakin kondusif dan sebagai pelindung bagi pekerja dalam menghadapi persaingan global ini. Upaya persiapan yang harus segera dibenahi adalah kualitas dan kuantitas tenaga pengawas 
ketenagakerjaan untuk melakukan pengawasan terhadap penerapan Undang-Undang Nomor 13 Tahun 2003 tentang Ketenagakerjaan tersebut.

Dari sisi kualitas, dengan adanya perubahan sistem pemerintahan yang awalnya sentaralistik menjadi desentralistik mengakibatkan kewenangan pemerintahan saat ini lebih banyak bertumpu pada pemerintahan kabupaten/kota. Dilain pihak tenaga kerja tidak saja bagi yang bekerja di sektor industri, tetapi ada pula yang bekerja dalam sektor perikanan dan pertanian, MEA akan mendorong liberalisasi pangan melalui integrasi kedua sektor tersebut. Indonesia for Global Justice (IGJ) menilai strategi dan persiapan Indonesia menghadapi Masyarakat Ekonomi ASEAN (MEA) berpeluang gagal. Ini ditandai dengan tidak adanya perubahan kebijakan guna memaksimalkan perlindungan bagi nelayan dan petani Indonesia pertumbuhan penduduk Indonesia masih tinggi, konsumsi pangan dan perikanan terus meningkat, serta 80\%-90\% kebutuhan konsumsi pangan domestik Indonesia bersumber dari produksi petani dan nelayan kecil. "Maka, kegagalan melindungi petani dan nelayan akan menggeser MEA dari peluang menjadi ancaman serius bangsa,"

Dengan berlakunya MEA, maka selain arus bebas bebas barang dan arus bebas jasa, arus bebas investasi, arus modal yang lebih bebas, juga termasuk arus bebas tenaga terampil dimana warga negara dapat keluar dan masuk dari satu negara ke negara lain mendapatkan pekerjaan tanpa adanya hambatan di negara yang dituju. Dalam berbagai diskusi dan pengalaman pengusaha akan lebih cenderung menggunakan tenaga lokal dari dalam negeri, karena akan beban produksi dari sisi tenaga kerja. Bila menggunakan tenaga kerja asing, pengusaha umumnya harus memberi upah lebih tinggi. Selain itu, akomodasi tak luput dari tanggung jawab pengguna jasa. Oleh karena itu, penggunaan jasa tenaga kerja dalam negeri dengan proporsi lebih banyak karena akan berpengaruh pada besarnya biaya yang harus dikeluarkan. Umumnya pengguna jasa tenaga kerja asing harus menanggung juga pajak pembinaan di luar gaji dan akomodasi.

\section{E. KESIMPULAN}

Masyarakat Ekonomi ASEAN (MEA) akan membentuk ASEAN sebagai pasar dan basis produksi tunggal membuat ASEAN lebih dinamis dan kompetitif dengan mekanisme dan langkah-langkah untuk memperkuat pelaksanaan baru yang ada inisiatif ekonomi; mempercepat integrasi regional di sektor-sektor 
prioritas; memfasilitasi pergerakan bisnis, tenaga kerja terampil dan bakat; dan memperkuat kelembagaan mekanisme ASEAN. Sebagai langkah awal untuk mewujudkan Masyarakat Ekonomi ASEAN.

\section{DAFTAR PUSTAKA}

Bagus Prasetyo.2013. Menilik Kesiapan Dunia Ketenagakerjaan Sektor Jasa Pegang Peranan Penting dalam Perekonomian Indonesia," diakses dari : http://satuharapan.com/index.php?id=109\&tx ttnews[tt news]=4222\& $\underline{\mathrm{cHash}}=1$

Departemen Perdagangan RI. 2013. Menuju Asean Economic Community 2015

Gilpin and Gilpin, 2000. General Agreements on Trade in Services dalam Peningkatan Daya Saing Industri Indonesia Guna menhadapi Asean - China Free Trade Area Agreement (ACFTA) dalam rangka memperkokoh ketahanan Nasional. Jurnal Kajian Lemhanas RI Edisi 14 Desember 2012.

http://id.voi.co.id/voi-komentar/4889-kesiapan-indonesia-menghadapimasyarakat-ekonomiasean- 2015

http://jakarta.bisnis.com/read/20141029/77/268648/mea-2015-hotel-restoran-di-d ki-tak-gentar-hadapi-tenagakerja-asing

http://www.hukumonline.com/berita/baca/lt52fc80c5beb6f/sektor-jasa-juga-diaturdalam-uuperdagangan

http://www.wartaharian.co/berita/nasional/ekonomi/9222-igj-indonesia-belum-siap -hadapimea- 2015.html

http://www.wto.org/english/docs_e/legal_e/26-gats_01_e.htm

Makmur Keliat, dkk. 2013. Laporan Penelitian "Pemetaan Pekerja Terampil Indonesia dan Liberalisasi Jasa Asean : Laporan Penelitian Asean Study Center UI bekerja sama dengan Kementrian Luar Negeri Republik Indonesia. Jakarta

Republika, Jumat, 19 April 2013. Sektor Jasa Berpotensi Naikkan Daya Saing Indonesia,", diakses dari http://www.republika.co.id/berita/ekonomi/makro/13/04/19/mlhx7a-sek tor-jasaberpotensi- naikkan-daya-saing-indonesia 